Uma Perspectiva Anti-realista sobre a Linguagem, o Pensamento, a Lógica e a História da Filosofia Analítica: uma entrevista com Michael Dummett

Fabrice Pataut

Université de Paris 1

Disputatio No. 3

November 1997

DOI: 10.2478/disp-1997-0008

ISSN: 0873-626X 


\title{
UMA PERSPECTIVA ANTI-REALISTA SOBRE A LINGUAGEM, O PENSAMENTO, A LÓGICA E A HISTÓRIA DA FILOSOFIA ANALÍTICA: UMA ENTREVISTA COM MICHAEL DUMMETT*
}

\author{
Fabrice Pataut ${ }^{1}$
}

\section{Frege e Wittgenstein}

FABRICE PATAUT - Prof. Dummett: o senhor é um dos filósofos mais proeminentes na tradição analítica e dedicou grande parte do seu tempo ao estudo de Frege, o qual fundou essa tradição há pouco mais de um século. Entre os filósofos analíticos, é raríssimo fazer-se isso. As pessoas têm tendência para não se preocuparem muito com o que os autores disseram de facto. Em geral, abordam os assuntos, por assim dizer, directamente; ou, pelo menos, muitos querem fazer isso. No prefácio à segunda edição do seu livro Frege: Philosophy of Language, disse que qualquer discussão frutífera das doutrinas de Frege teria de ficar adiada até que se tenha chegado a acordo sobre o conteúdo básico dessas doutrinas. ${ }^{2}$ Ora, num certo sentido, boa parte da filosofia tal como é praticada na tradição analítica consiste na discussão destas doutrinas e não parece que já se tenha atingido qualquer acordo quanto à sua correcta interpretação, para não do acordo quanto aos princípios da exegese da filosofia de Frege. Permita-me que comece com uma pergunta deliberadamente ingénua: o que é que torna o caso de Frege

\footnotetext{
* Publicado com a amável autorização de Fabrice Pataut.

${ }^{1}$ A entrevista teve lugar em Oxford no dia 10 de Setembro de 1992. Quando estava a transcrevê-la, decidi reunir as referências bibliográficas em notas de rodapé de modo a que o leitor pudesse ter a sensação do fluir da conversa. Dividi depois o texto em secções, de acordo com os tópicos discutidos. Algum do material originalmente transcrito foi subsequentemente rearranjado. Agradeço a Michael Dummett a sua paciência, e a ele e a Anne Dummett a sua hospitalidade. Timothy Tessin ajudou a preparar o texto para publicação.

${ }^{2}$ Frege: Philosophy of Language, Duckworth, Londres, 1. ${ }^{\mathrm{a}}$ ed., 1973; Harvard University Press, Cambridge, Mass., 2. ${ }^{a}$ ed., 1981, p. xv.
}

\section{Disputatio 3, Novembro 1997}


tão especial? Que podemos concluir do facto de não se ter chegado a qualquer acordo quanto ao conteúdo básico das doutrinas de Frege? Há grandes divergências acerca delas e, no entanto, podemos descrever a filosofia analítica como uma constante reformulação e discussão do que Frege iniciou e uma tentativa para resolver os problemas que ele introduziu.

Michael DummetT - Acho que é verdade. A última observação que fez tem muito de verdadeira, porque Frege conseguiu formular questões de uma maneira à qual ainda somos sensíveis. Quando se estudam os filósofos do passado, em quase todos os casos, temos primeiro de reformular os seus problemas antes de os discutirmos. Com Frege, eles estão já formulados de uma maneira com a qual sentimos afinidades. Não nos afastámos tanto dele que achemos as suas formulações equívocas. Claro que há coisas que Frege não viu ou das quais não tinha consciência e das quais nós tomámos consciência. Mas ele continua a ser um excelente ponto de partida, em minha opinião, para muitíssimas famílias de problemas filosóficos.

O fenómeno de que fala surpreendeu-me e ainda me surpreende um pouco. Quando escrevi o meu primeiro livro sobre Frege, não pensei que houvesse grandes razões para controvérsia acerca do que ele queria dizer. ${ }^{3}$ Pensava que era preciso reflectir muito sobre isso, não tanto para determinar o que ele queria dizer mas, sobretudo, para analisar profundamente cada questão e ver todas as suas implicações. Foi então que fiquei espantado ao ler algumas coisas - livros, artigos, etc. - que propunham interpretações radicalmente novas de Frege, a maior parte das quais me pareciam perversas. E não consigo explicar cabalmente este fenómeno. Imagino que a frase que citou foi escrita provavelmente num estado de espírito de irritação.

FP - Foi, pelo menos, uma maneira bastante radical de formular a sua ideia.

MD - Sim, tem razão, e já não a subscrevo. Claro que podemos discutir Frege antes de chegarmos a um acordo total. Mas é muito irritante. E esta situação continua. Há alguns livros que não são mais do que exercícios que consistem em dizer «Bem, antes de mim, ninguém compreendeu o que Frege queria dizer». Acho que é idiota. Não penso sequer que possa ser verdade.

${ }^{3}$ Frege: Philosophy of Language foi seguido de: The Interpretation of Frege's Philosophy, Duckworth, Londres, 1981; Frege and Other Philosophers, Clarendon Press, Oxford, 1991; e Frege: Philosophy of Mathematics, Duckworth, Londres, 1991. 
Claro que as pessoas podem ver coisas que as outras não viram. Mas a ideia de que toda a gente se equivocou completamente até este momento acerca do que ele queria dizer... É demasiado improvável para ser aceite. Mas eles continuam. Não sei por que razão Frege, em particular, atrai isto. Não fazem isso com Russell. Nem sequer o fazem com Kant, não é?

FP - Fazem-no com Wittgenstein. Ele parece atrair sobretudo esse tipo de coisa.

MD - É perfeitamente verdade. Mas também é verdade que Wittgenstein é muito mais obscuro do que Frege, por causa da maneira como escrevia. Muitas vezes, deixava ao leitor a tarefa de completar o raciocínio.

FP - Muitas das observações de Wittgenstein são susceptíveis de várias interpretações. Há muitas frases e parágrafos que parecem conter observações desconexas.

MD - E perguntas não respondidas e coisas do género. Temos de perguntar: «Por que aparece este parágrafo nesta altura? Por que pôs ele isto aqui?». Portanto, acho que é mais compreensível. E também acho que estamos muito longe de compreendermos Wittgenstein completamente. Portanto, talvez a verdade surja através de argumentos deste género, mas não creio que haja lugar para argumentos desse género no caso de Frege. Há certamente lugar para argumentos acerca da avaliação das suas doutrinas. Mas parece-me muito claro aquilo que são.

FP - Isso leva-me a outra questão acerca de Wittgenstein. Disse que começou a sua carreira filosófica considerando-se um seguidor de Wittgenstein, pelo menos até 1960 . $^{4}$ Tenho três perguntas sobre isto. Em primeiro lugar, o que significava para si, nessa altura, ser seguidor de Wittgenstein? Em segundo lugar, empreendeu o seu estudo de Frege - que lhe tem ocupado toda a vida - adoptando um ponto de vista filosófico que se poderia denominar wittgensteiniano? Por fim, concebeu aquilo que se poderia denominar como o seu trabalho sobre Frege (por oposição ao seu combate contra o realismo) como uma tarefa completamente independente da sua perspectiva filosófica?

MD - É claro que me dediquei ao estudo de Frege adoptando já um ponto de vista filosófico, porque ninguém lê um autor filosófico sem uma ideia prévia. Mas de certeza que isso não acontecia conscientemente no

${ }^{4}$ Truth and Other Enigmas, Harvard University Press, Cambridge, Mass., 1978, p. xii. 
sentido em que pudesse dizer «agora vou olhar para Frege da perspectiva de Wittgenstein», ou coisa do género. Eu não via as duas coisas como separadas e de facto não têm estado para mim separadas, justamente porque as questões de Frege são, em larga medida, questões. O estudo da obra de Frege tem sido, para mim, em grande medida, um ponto de partida para pensar acerca de várias questões filosóficas. Claro que, quando escrevemos acerca de um autor específico temos de ser bastantes expositivos e por aí fora, mas, como sabe, especialmente no primeiro livro, tentei fazer disso o ponto de partida para depois discutir uma série de questões filosóficas. Nesse livro, há muito que não é realmente nada sobre Frege, mas que foi apenas motivado pela exposição sobre ele.

FP - Essa foi uma das queixas de Hans Sluga. ${ }^{5}$

MD - Foi uma das queixas dele, e tenho de admitir que havia nelas alguma justiça, embora discorde de alguns pormenores. Não creio que a descrição que ele tentou fazer do contexto histórico de Frege seja realmente convincente. Mas é perfeitamente verdade que quando escrevi esse primeiro livro não estava suficientemente atento à situação em que o próprio Frege se encontrava. E acho que isso é necessário. Pensava muito mais nas conexões entre o seu trabalho e o que aconteceu a seguir. Acho que, quando se lê um filósofo, tem se de perguntar: «Como é que o problema foi posto naquela altura, dado o tipo de coisas que as outras pessoas então diziam?»

FP - No que diz respeito a Frege $e$ a Wittgenstein, afirmou que a concepção de Wittgenstein sobre o carácter social do significado, identificando-o com o uso, fora antecipada pela ideia de Frege da objectividade do Sinn. ${ }^{6}$ Não será isto uma maneira de ver Frege a partir de uma espécie de ponto de vista wittgensteiniano?

${ }^{5}$ Hans Sluga, Gottlob Frege, Routledge and Kegan Paul, Londres, 1980.

${ }^{6}$ "What is a Theory of Meaning? (II)», Truth and Meaning - Essays in Semantics, G. Evans e J. McDowell, orgs., Clarendon Press, Oxford, 1976, p. 135: «A tese de Frege de que o sentido é objectivo antecipa assim implicitamente (a respeito daquele aspecto do significado que constitui o sentido) a doutrina de Wittgenstein de que o significado é o uso (ou então uma de entre a família de doutrinas assim formuladas) [...]» [Nota do Tradutor: Ao longo desta entrevista, o termo «sentido» traduz «sense» (correspondente por sua vez ao «Sinn» de Frege, tradicionalmente oposto a «Bedeutung», referência), ao passo que o termo mais genérico «meaning» é traduzido por «significado». Esta convenção segue aquela fixada na edição portuguesa do Oxford Dictionary of Philosophy, de Simon Blackburn (Dicionário de Filosofia, Gradiva, 1997)]. 
MD - Não tenho a certeza. Em Frege, a ênfase é posta, muito fortemente, na comunicabilidade dos pensamentos, dos Gedanken, e no facto de eles nos serem comuns a todos.

FP - E isso está em oposição directa com a incomunicabilidade das representações, das Vorstellungen.

MD - Exacto. Ora, não há, em Wittgenstein, o mesmo tipo de rejeição da ideia da incomunicabilidade da vida mental interior. Acerca de Frege poderia dizer-se que há uma ênfase na comunicabilidade de algo que é acessível a todos, mas não há uma exploração detalhada desta ideia. Ele nunca chega a discutir como é que podemos todos atribuir o mesmo sentido às nossas frases.

FP - E também não dá qualquer explicação sobre aquilo em que consiste a apreensão dos pensamentos propriamente dita. Existe, por assim dizer, o acto primitivo de apreender.

MD - Exacto. É apenas um facto.

FP - Nesse caso, pensa que a ideia de Wittgenstein é uma maneira de explorar a intuição de Frege?

MD - Penso que pode certamente ser vista desse modo. É muito difícil ter a certeza. É óbvio que ele foi profundamente influenciado por Frege. Ele parece-me normalmente estar ao seu pior nível quando critica Frege. Não porque Frege tem sempre razão e Wittgenstein nunca tem, mas porque ele é bastante simplista quando está a criticar Frege. Não sei porquê. É óbvio que muita dessa influência não se percebe à primeira vista. Ele nem sempre se refere explicitamente a Frege e nem sempre reconhece a sua influência quando deve. Acho que, provavelmente, a génese dessas ideias pode ter sido a leitura que ele fez de Frege. Não tenho a certeza.

FP - Há outra característica da sua interpretação de Frege que merece ser destacada: a ênfase na ideia de Frege de que compreender o significado de uma frase, i.e., o pensamento expresso pela frase, é saber as suas condições de verdade, ou se essas condições são satisfeitas ou não. Salvo erro, Frege defende esta ideia explicitamente apenas uma vez, designadamente nos Grundgesetze, \$32. ${ }^{7}$ Mas o Prof. Dummett vê nesta ideia, em particular,

${ }^{7}$ Gottlob Frege, Grundgesetze der Arithmetik, Begriffschriftlich abgeleitet, Band I, H. Pohle, Jena, 1893. Tradução inglesa de M. Furth do prefácio, introdução e $\$ \S 1-52$ em: The Basic Laws of Arithmetic: Exposition of the System, University of California Press, Los Angeles, 1964. Este é o texto relevante de Frege: «Cada nome [...] de um 
uma das pedras de toque do realismo de Frege; e a sua própria argumentação contra o realismo é, efectivamente, dirigida contra a chamada teoria verocondicional do significado. Pensa que esta era de facto uma preocupação central de Frege?

MD - Absolutamente. Acho que se relaciona de muito perto com a sua oposição à intrusão da psicologia na lógica. Pense só nas coisas que ele diz nos Grundlagen sobre as definições psicologistas ${ }^{8}$. Quando não se consegue definir um conceito matemático básico, este é definido em termos das operações mentais necessárias para apreender o conceito. O que ele diz sobre isto é que não se pode usar uma definição desse tipo para demonstrar o que quer que seja. Concordo que esta observação não é directamente sobre condições de verdade. Mas pense só: quando é que se pode usar uma definição para demonstrar algo? Justamente quando ela nos diz sob que condições uma frase que contenha o termo definido seria verdadeira. Se ela fizer isso, ou ajudar a fazer isso, então podemos usá-la para demonstrar que uma certa frase específica é verdadeira. É por isto que penso que é uma ideia fundamental em Frege.

Acaba de falar na contenda realismo versus anti-realismo. O que é muito notório em Frege é que ele se abstém sempre de dizer que as condições de verdade têm a ver com o modo como nós atribuímos o valor de verdade. Muitas vezes, há até um aviso explícito: por exemplo, quando ele está a defender que os predicados devem ser sempre definidos e que se deve sempre determinar, para qualquer objecto, se ele cai debaixo do conceito ou não. Normalmente ele acrescenta: nós podemos não ser capazes de determinar isso embora isso seja, por assim dizer, objectivamente determinado. A realidade determina-o; é qualquer coisa deste género. Portanto a recusa em for-

valor de verdade exprime um sentido, um pensamento [drückt einen Sinn, einen Gedanken aus]. Designadamente, por estipulações nossas, fica determinada sob que condições [Bedingungen] o nome denota [bedeutet] o Verdadeiro. O sentido deste nome - o pensamento - é o pensamento de que estas condições são satisfeitas [dass diese Bedingungen erfüllt sind]».

${ }^{8}$ Gottlob Frege, Die Grundlagen der Arithmetik. Eine logish-mathematische Untersuchung über den Begriff der Zahl, W. Koebner, Breslau, 1884. Trad. inglesa de J. L. Austin: The Foundations of Arithmetic - A logico-mathematical enquiry into the concept of number, Basil Blackwell, Oxford, 1950 (trad. port: Os Fundamentos da Aritmética, 1992). Ver em especial a introdução, pp. iii, vi, viii-ix e parte II, §§26, 27. 
mular isto nos termos em que Wittgenstein o teria formulado - em termos do que nós podemos fazer - é de facto bastante consciente.

\section{Inconsistência, holismo, harmonia e intuicionismo}

FP - Deixe-me regressar a Wittgenstein. A minha próxima pergunta diz respeito ao modo como se deve entender o famoso lema «o significado é o uso» e como se deve determinar as suas implicações filosóficas ${ }^{9}$. Este é um grande problema e tem a ver, de novo, com a oposição entre ser um wittgensteiniano e não ser um wittgensteiniano, no seguinte sentido. Muitas pessoas acham que nenhuma interpretação desse famoso lema de Wittgenstein poderia levar, ao contrário do que o Prof. Dummett defende, a uma revisão das leis da lógica clássica. Não estou a falar das pessoas preocupadas com o que Wittgenstein realmente queria dizer. Parece-me que muitas pessoas querem resistir à ideia de que algo de certo modo tão «óbvio» como «o significado é o uso» poderia conduzir a algo tão drástico. Porque pensa que conduz?

MD - Vou tentar responder. Fundamentalmente, porque não aceito o holismo, do modo como penso que Wittgenstein o aceitava - ou, pelo menos, do modo como estava comprometido com ele. Conhece certamente a famosa tese de Wittgenstein de que a filosofia não pode alterar absolutamente nada, pode apenas descrever, etc... Em particular, ele tinha a ideia de que não se pode alterar a prática linguística, e deixou-se enredar na tese absurda de que a filosofia não poderia alterar a prática linguística nem que se mostrasse que essa prática era inconsistente ou levava a contradições. Têm de se aceitar as contradições com um facto.

FP - Mas a nossa prática linguística poderia certamente ser inconsistente.

MD - Tarski acreditava que era, essencialmente, inconsistente.

\footnotetext{
${ }^{9}$ Ver Wittgenstein, Philosophische Untersuchungen, trad. inglesa de G. E. M. Anscombe, Basil Blackwell, Oxford, 1958 (trad. port.: Tratado Lógico-Filosófico/Investigações Filosóficas, Gulbenkian, 1987), parte I, §43: «Para uma grande classe de casos - embora não para todos — do emprego da palavra «significado», pode dar-se a seguinte explicação: o significado de uma palavra é o seu uso na linguagem [Die Bedeutung eines Wortes ist sein Gebrauch in der Sprache].»Ver também Investigações Filosóficas, parte I, $\S \S 120,138,190,432$ e as páginas iniciais de The Blue and Brown Books, Basil Blackwell, Oxford, 1958 (trad. port.: O Livro Azul, 1992 e O Livro Castanho, 1992).
} 
FP — A prática linguística concreta é muitas vezes inconsistente.

MD - Bem, «a prática linguística concreta»... O que é que se quer dizer com isso? Não poderia haver uma prática segundo a qual as pessoas asserissem apenas contradições. Se quiser dizer que uma prática é contraditória, tem de dizer que há princípios gerais que as pessoas seguem e seriam capazes de reconhecer como tal. Quero com isto dizer que poderiam reconhecer que seguem estes princípios. Se insistíssemos, identificariam também quais são aqueles que conduzem a contradições. O ponto principal é que poderíamos levá-las a fazer isso.

FP - Portanto, as pessoas contradizem-se a si próprias. Isso não é uma prática? Por que não dizer que elas praticam a contradição?

MD - Pode dizer isso. Mas nesse caso tem de circunscrever o âmbito de aplicação da sua frase e reconhecer que eles também podem perceber que o que disseram necessita de alguma revisão. Há uma distinção entre um indivíduo que se contradiz mas que saberia reconhecer esse erro, assim como a sua origem, e a própria linguagem ser inconsistente, que era o que preocupava Tarski em relação às linguagens naturais. O que quer dizer que há princípios gerais, que todos identificariam, que regem o uso da linguagem; e a natureza desses princípios faz com que as pessoas saibam reconhecer que conduzem à contradição, se insistirmos com elas. É isto que os paradoxos são. Quando são postas perante paradoxos, as pessoas não sabem o que hão-de fazer porque foram conduzidas a uma contradição através de passos que pareciam absolutamente irrecusáveis. De modo que lhes viram, pura e simplesmente, as costas. Claro que é então que os filósofos começam a preocupar-se com o assunto.

O aspecto importante na nossa discussão sobre o holismo é o seguinte: Wittgenstein pensava - e eu discordo totalmente deste ponto de vista que na prática linguística, e em particular no uso de formas de inferência, nada necessita de justificação nem pode ser criticado. Se é a prática que é absurda, isso já é justificação suficiente. Não precisa de mais justificação. Ora, isto parece-me estar errado porque as inferências não são coisas separadas do resto da linguagem. Uma inferência não é apenas um jogo como as palavras cruzadas, que não afecta mais nada. Conduz a asserções e a conclusões, e essas conclusões podem conter constantes lógicas. Portanto temos de perguntar: «Como são elas usadas? Como reagimos a tais asserções? Que consequências devemos tirar delas?»e assim por diante. 
Parece-me que há a possibilidade de uma discrepância entre o modo como raciocinamos e o modo como utilizamos as conclusões a que chegamos através do raciocínio. Um processo de raciocínio tem de se justificar com base no facto de conduzir a coisas que estamos justificados em asserir de acordo com os significados que lhes atribuímos.

FP - E, em particular, de acordo com o significado que atribuímos às constantes lógicas?

MD - Exactamente. Portanto há uma exigência de consonância, por assim dizer, entre diferentes partes de uma prática linguística, algo extremamente complicado e que não nos permite dizer «bem, acontece que raciocinamos assim, é a isso que chamamos "raciocínio" e pronto».

FP - Portanto, é a exigência de harmonia que torna necessária a rejeição do holismo e que nos obriga a interpretar «o significado é o uso» como algo que conduz à revisão de certos padrões de raciocínio, como, por exemplo, os baseados nas leis da lógica clássica. Isto é muito anti-wittgensteiniano.

MD - É o ponto em que eu divirjo completamente de Wittgenstein. Não creio que alguma vez tivesse havido alguma justificação na sua afirmação de que a filosofia não pode interferir em nada. A nossa prática linguística pode ser anómala tal como o nosso comportamento pode ser anómalo ou irracional. A filosofia tem o direito de fazer notar isso mesmo.

FP - Acha que os padrões clássicos de raciocínio e as leis da lógica clássica são mesmo inconsistentes e levam a contradições?

MD - Não acho que sejam propriamente inconsistentes. Não acho que conduzam a algo tão mau como contradições. Acho que conduzem ou podem conduzir à desarmonia que mencionou. Ao usar certos esquemas de raciocínio, somos levados a asserir coisas para as quais não temos de facto justificação, dado o significado que atribuímos às nossas palavras.

FP - Vejamos um caso típico. Suponhamos que alguém usa a regra da eliminação da negação dupla, i.e., infere $p$ a partir de $\neg \neg p$. Um intuicionista rejeitaria esta inferência como inválida. Mas o que há de errado em usar esta lei da lógica? Se isso for assim, deve ser verdade que não podemos asserir $p$ com base em $\neg \neg p$. Mas por que razão não pode $\neg \neg p$ constituir justificação suficiente para $p$ ?

MD - Não é justificação suficiente em si. Claro que há muitos casos em que esta inferência é perfeitamente aceitável, e esses casos incluem todos aqueles em que nós estamos em condições de decidir a questão. Mas em geral, quando se trata de algo que não temos meios para decidir, há um 
problema. Tudo depende de como se entender a negação. Se, como fazemos normalmente, ela for entendida de tal modo que, para asserirmos a negação de uma frase $p$, é suficiente mostrar que não poderíamos estar em posição de asserir $p$, então o facto de não podermos estar em posição de asserir a própria negação de $p$ não garante, certamente, que estamos em posição de asserir a própria frase $p$.

FP - Mas, se pudéssemos de facto determinar o valor de verdade de $p$, constituiria isso uma justificação suficiente para a asserção?

MD - Claro, caso contrário ficamos com uma coisa mais fraca. A ilusão vem da imagem que nós temos de uma realidade determinada que podemos não ser capazes de observar mas que, no entanto, tem de estar fixada num sentido ou no outro. Não é falso? Bem, então tem de ser verdadeiro. É simples. É uma imagem a que é, psicologicamente, difícil resistir e que nós usamos.

Olhe, isto não tem exactamente a ver com regras de inferência, mas tem muito a ver com imagens realistas. Há uma crença esmagadoramente maioritária no determinismo. Não vou falar na mecânica quântica. Isso é outro problema. Quer dizer, é mais uma razão pela qual as pessoas não devem acreditar no determinismo. Mas esqueça a mecânica quântica. Pense só nos sistemas caóticos. Os defensores dos sistemas caóticos determinísticos disseram-me que se tivéssemos uma ideia exacta das condições iniciais, os estados subsequentes desse sistema seriam completamente determinados. O problema é o seguinte: não podemos prevê-los porque não podemos jamais ter uma ideia exacta das condições iniciais, e uma pequena variação agora produz uma grande variação mais tarde. Portanto, eles defendem que, apesar de imprevisível, o sistema é no entanto determinístico.

Ora, dizer que o sistema é determinístico é presumir que há valores exactos nas condições iniciais das quantidades, representados por números reais. Mas isso não é mais do que a imposição de um tipo de imagem matemática - a do contínuo matemático - sobre a realidade, a qual de facto não condiz de maneira nenhuma com a nossa experiência. Toda a gente está sempre a dizer que quando medimos, medimos só até um certo grau de precisão, etc. Se não presumirmos à partida que estas quantidades têm, nesse sentido, grandezas absolutamente determinadas, ficamos sem qualquer argumento para o determinismo. Dizer que o sistema é determinístico é apenas um comentário sobre a matemática do sistema. 
FP — É apenas, por assim dizer, uma característica da matemática do sistema.

MD - Exactamente. A premissa subjacente é a de que todas estas quantidades têm grandezas absolutamente determinadas, dadas por números reais.

FP — É isso que a chamada teoria do valor escondido em parte significa.

MD - Exactamente. E é apenas algo imposto por esta maneira de pensar.

FP - Era o ponto de vista de Einstein.

MD - Mas isso em reacção a alguns problemas específicos da mecânica quântica. Não é disso que eu estou a falar. A maior parte dos físicos aceitam, claro, o contínuo clássico como um bom modelo da realidade física, mas penso que ficariam melhor se usassem o contínuo intuicionista. Estamos sempre a progredir em direcção a valores determinados, mas nunca chegamos a eles.

FP — Falemos de Wittgenstein e da relação entre Wittgenstein e o intuicionismo. Uma das coisas de que as pessoas não gostam no intuicionismo é o tipo de filosofia subjectivista ou mesmo solipsista que implica, ou pelo menos com a qual o intuicionismo de Brouwer estava comprometido. Pensa que a perspectiva de Wittgenstein sobre o carácter social do significado fornece uma saída? Suponhamos que «o significado é o uso» conduz de facto a uma revisão da lógica clássica. Se aceitarmos uma tal interpretação dessa parte da filosofia do segundo Wittgenstein, conseguiremos realmente separar o intuicionismo do solipsismo, do tipo de subjectivismo com que é normalmente identificado?

MD - Penso que sim. Brouwer, claro, parece ter sido realmente um solipsista genuíno. Acho que não acreditava de facto na existência de outras pessoas. Tome como exemplo a suposta linguagem dos dados dos sentidos, ela própria uma linguagem solipsista. Se uma tal linguagem existisse, teria de se ter um trabalho monstruoso para passar dela para a linguagem dos objectos físicos. Mas o caso matemático é bastante diferente. $\mathrm{O}$ contraste com a matemática é óbvio e Brouwer está, é claro, completamente errado quanto à incomunicabilidade das estruturas matemáticas. O que é notório na matemática é justamente a sua comunicabilidade. Não há nada numa ideia matemática que não possa ser comunicado. E a coisa mais espantosa é que não se tem de fazer nada, no sentido em que, se tivermos a descrição de uma teoria matemática em termos das construções que um matemático específico produz na sua mente, não temos de fazer virtualmente nada para transformar 
isso numa descrição das construções que podem ser comunicadas de um matemático para outro. Porquê? Porque a teoria de Brouwer pode ser transformada, sem qualquer alteração excepto nos aspectos de fundo, numa teoria, por assim dizer, da matemática comunitária. Isto não poderia acontecer em qualquer outro domínio do discurso. No caso do mundo físico, haverá sempre uma discrepância enorme entre o mundo que todos nós habitamos e o mundo que $e u$ observo. Mas no caso matemático essa discrepância não existe e é por isso que o solipsismo - que eu concordo completamente ter constituído e motivado parte da filosofia geral de Brouwer - não tem realmente importância.

\section{Austin, Ryle e Carnap}

FP - Posso voltar a Wittgenstein? No Prefácio a Truth and Other Enigmas (p. XII) afirmou que o tipo de trabalho que Wittgenstein fazia - pelo menos, acho eu, nas Investigações Filosóficas - o vacinou contra a influência de Austin. Como é que pensa que a obra de Wittgenstein ajuda a combater o tipo de argumentação de Austin baseada em «casos paradigmáticos» e a sua maneira deliberadamente assistemática de analisar a linguagem, i.e., contra a filosofia da linguagem comum que dominou Oxford a certa altura? Além disso, acha que a filosofia analítica deveria ou poderia ser sistemática?

MD - A observação que fiz a respeito de Austin foi apenas de carácter histórico, digamos, a respeito de mim próprio. É verdade que esta oposição ao sistema é partilhada pela a filosofia da linguagem comum de Wittgenstein e de Austin; a ideia é que se tem de investigar as coisas uma de cada vez, etc. Mas penso que a grande diferença entre Wittgenstein e pelo menos aquilo que Austin professava, ou aquilo que ensinava, era que Wittgenstein começava sempre com problemas filosóficos e se debatia com eles, ao passo que Austin achava que os problemas filosóficos resultavam de confusões, de mal-entendidos acerca da nossa linguagem, erros linguísticos que se cometem.

Wittgenstein pensava certamente, como Austin, que tinha muito a ver com a linguagem. Mas ele partia dos problemas, ao passo que Austin ensinava realmente — não sei se isto se aplicava à sua própria prática filosófica - que devemos esquecer os problemas filosóficos. Temos de começar por olhar para as palavras e para o modo como são usadas, fazer análises muito precisas desses usos e assim por diante, deixando de lado os problemas 
filosóficos que existirem; depois, dar-se-á um milagre e todos os problemas filosóficos se dissiparão. Foi sobretudo isto que me pareceu deitar por terra a reflexão filosófica tal como eu a entendia. A motivação para toda a actividade filosófica vem das perplexidades com que nos deparamos quando começamos a pensar sobre o arbítrio humano, ou o tempo ou o que quer que seja. E ensinar às pessoas que devem ignorá-las, bem...

FP - Há outra tradição na filosofia analítica. Estou a pensar na influência que Carnap teve nos Estados Unidos. Carnap era um filósofo sistemático e teve uma enorme influência em Reichenbach, Quine, Goodman, Putnam, etc. Há gerações inteiras de filósofos americanos que acharam que a filosofia era o que Carnap pensava que ela era ou que o tomavam como modelo, e para Carnap o objectivo da filosofia era a construção de um sistema. Pensa que ele estava mais perto do ponto de vista correcto acerca do que um projecto filosófico deve ser? Aqui, é claro, ele quase não teve influência nenhuma.

MD - Isso é por causa de Ryle. Só mais uma coisa sobre Austin. Sempre pensei que Austin foi cego no que diz respeito ao tópico da reflexão filosófica. Era um homem muito inteligente, mas sempre considerei que a sua influência foi extremamente nefasta. Quanto a Ryle, não achava a mesma coisa dele. Vim a achar gradualmente, mas na altura não. Pelo contrário, acreditava nele, ou provavelmente acreditava em muito do que Ryle dizia. Ele estava completamente contra Carnap. Considerava Carnap como o pior dos filósofos, achava que ele cometia erros triviais, e devido a isso passou muito tempo até que eu lesse qualquer coisa de Carnap e o levasse a sério. Cresci, por assim dizer, como estudante de filosofia em Oxford, quando Ryle era rei. Ele teve uma influência tremenda. Austin veio um pouco depois. Eu pensava que não havia necessidade de prestar atenção a Carnap só porque Ryle dizia que não e porque fazia pouco dele. Portanto, a minha situação é muito diferente da daquelas pessoas para quem Carnap era a grande autoridade.

FP - Basta pensar na sua influência em Quine e em Goodman.

$\mathrm{MD}-\mathrm{E}$ verdade. The Structure of Appearance, que foi o primeiro livro de Goodman, foi um esforço, uma tentativa, para fazer a mesma coisa do que a logishe Aufbau. Eu achava, e de facto ainda acho, que este é um em- 
preendimento completamente equivocado. ${ }^{10}$ Penso que o ponto de vista de Wittgenstein segundo o qual não existem teses filosóficas que a filosofia possa realmente afirmar, e que tudo o que ela pode fazer é lembrar-nos de coisas que já sabíamos antes, é um ponto de vista errado. Há teorias a construir. Mas as teorias de Carnap, propriamente ditas, não me impressionam muito. Há algo de muito estéril nelas. Portanto, para mim, a revolta de Quine é muito compreensível.

Como hei-de explicar isto? Conhece a história do irlandês? Uma pessoa perde-se e pergunta a um irlandês: «Como é que se vai para Dublin?» O irlandês pensa um bocado e diz: «Se eu fosse para Dublin, não partia daqui». Acho que foi realmente uma pena ter-se partido de Carnap.

FP - Isso pode ser verdade, mas podem-se encontrar muitas preocupações em Carnap - por exemplo no extenso artigo «Testability and Meaning» — que estão de facto muito próximas do tipo de coisas que o preocupam a si. ${ }^{11}$ Estou a pensar especialmente na teoria verificacionista do significado e da maneira como ele tenta corrigi-la, substituindo a noção de verificação pela noção mais respeitável de confirmação gradual, entendida em termos probabilísticos. Estou a pensar também na sua rejeição da ideia ingénua de que as asserções não verificáveis não têm significado, um indício seguro de que havia algo de errado com o primitivo critério positivista de significado ou de significado cognitivo. Todas estas preocupações estão muito próximas das questões fundamentais do debate realismo versus anti-realismo tal como o Prof. Dummett o concebe.

$\mathrm{MD}$ - Provavelmente é verdade. $\mathrm{O}$ facto de eu não ter prestado qualquer atenção a Carnap deve ser um efeito tardio do ensino de Ryle.

\section{A filosofia analítica, a sua história e a tese da prioridade}

FP - Deixemos então Carnap de lado. Deixe-me passar para outra questão. Recentemente, mostrou algum interesse pela história da filosofia.

${ }^{10}$ Rudolph Carnap, Der logische Aufbau der Welt, Weltkreis - Verlag, Berlim, 1928; trad. ingl. de R. A. Berkeley: The Logical Construction of the World, University of California Press, Berkeley, 1967. Nelson Goodman, The Structure of Appearance, Harvard University Press, Cambridge, Mass., 1951. Ver a análise que Dummett faz deste último em Truth and Other Enigmas, cap. 3, pp. 29-37.

${ }^{11}$ Rudolph Carnap, «Testability and Meaning», Philosophy of Science, vol. 3 (Out. 1936), pp 419-71 [sec. I-III]; vol. 4 (Jan. 1937), pp.1-40 [secção IV]. 
Defende, logo no início de Origins of Analytical Philosophy, que a filosofia analítica tem de compreender a sua própria história ${ }^{12}$. Suponho que isto foi motivado pelas queixas de Sluga acerca do seu primeiro livro.

MD - Possivelmente foi. Indirectamente. Isto é: os comentários de Sluga convenceram-me, depois de um bocado, que eu não tinha prestado suficiente atenção ao contexto histórico de Frege. Mas também, como disse, a sua própria análise histórica não me impressionou muito. Em particular, fiquei muito mal impressionado com a sua recusa em prestar o mínimo de atenção a Husserl. Nesse livro sobre Frege, afirma que seria interessante fazer uma comparação entre os dois, mas que isso está fora do âmbito da obra. A mim parece-me que se se está a escrever um livro sobre Frege e sobre o seu contexto histórico, é precisamente isso que se deve fazer. Não há nada de muito frutuoso em toda aquela coisa sobre Lotze e não sei que mais.

Mas não foi apenas em resposta a Sluga. Foi também por causa de Herman Philipse, um filósofo holandês que por acaso estava em Oxford em 1982 ou 1983 e que queria dar um seminário sobre as Investigações Lógicas de Husserl. Contactou-me, em parte, imagino eu, porque era apenas visitante e não sabia se iria ter alunos se desse um seminário ou se lhe era mesmo permitido dar o seminário. Ofereci-me para dá-lo com ele. Em resultado disso, como é óbvio, comecei a dedicar-me à leitura das Investigações e fiquei muito interessado. Portanto, foi uma combinação de várias coisas. A outra motivação foi responder às perguntas a que Sluga não tinha respondido.

FP - Qual é o interesse filosófico de uma compreensão desse tipo, uma compreensão da história da filosofia analítica, para além do interesse histórico ou cultural em geral? A grande maioria dos filósofos analíticos acha que, do ponto de vista filosófico, é completamente irrelevante.

MD - Sim. Mas olhe que no começo do século, digamos na altura em que Husserl publicou as Investigações Lógicas, a fenomenologia ainda não existia enquanto escola. A filosofia analítica ainda não existia enquanto escola. Existiam várias correntes e qualquer pessoa teria colocado Frege e Husserl muito próximos um do outro; e contudo o legado dos dois divergiu

${ }^{12} \mathrm{O}$ texto original da série de conferências dadas na Universidade de Bolonha em 1987 apareceu em Lingua e Stile, Anno XXIII, 1988, pp. 3-49, 171-210. Uma versão revista foi depois publicada sob o título Origins of Analytical Philosophy, Duckworth, Londres, 1993. A partir de agora tomo esta edição como referência. 
muitíssimo. É uma questão muito interessante, que de certeza vai elucidar muita coisa. Por que divergiram tanto? Outra maneira de formular isto é a seguinte. Na própria tradição analítica, há agora algumas pessoas — Gareth Evans foi um dos primeiros - que rejeitam aquilo a que eu uma vez chamei o teorema fundamental da filosofia analítica, a prioridade da linguagem sobre o pensamento.

$\mathrm{FP}$ - A tese da prioridade.

MD - Sim, a tese da prioridade. No entanto, eles estão muito claramente na tradição analítica. Não creio que Evans alguma vez tenha lido uma palavra de Husserl em toda a sua vida. No seu livro, Russell, Frege e Moore eram as grandes referências. ${ }^{13}$ Agora há outras pessoas. Cristopher Peacocke é outro. Isso coloca uma questão: «o que é essencial à filosofia analítica?» Antes, poder-se-ia ter dito que era a tese da prioridade. Todos a aceitavam. Mas isso já não é verdade. Estas pessoas são filósofos analíticos? É bastante óbvio que são, porque o tipo de análise que praticam é muito semelhante a (ou pelo menos é derivada de) uma teoria fregeana do significado, de uma semântica fregeana ou qualquer coisa desse género. Portanto, a questão de determinar o que é essencial à filosofia analítica é de facto uma questão muito interessante. Mas como se pode entender isso se não se voltar às suas origens? O que distingue este tipo de filosofia dos outros? De onde parte a divergência? Portanto, acho que há muito trabalho a fazer.

Outra coisa que não discuti no meu primeiro livro, mas pode elucidar muita coisa, acho, é o facto de não percebermos realmente a relação entre Wittgenstein e o Círculo de Viena. Por causa do Tractatus. Esse é que é o livro. Wittgenstein tinha um profundo respeito por Frege. Mas o Tractatus é da escola de Russell muito mais do que da escola de Frege. Foi escrito no ambiente de Cambridge, não é? Os problemas sobre os quais ele tinha pensado eram problemas sobre os quais Russell, Ramsey, etc., também tinham pensado. E depois teve um impacto enorme em pessoas completamente diferentes, num ambiente completamente diferente, em Viena. O que aconteceu ao certo? Qual era a relação entre Wittgenstein e estas pessoas? Não consigo perceber e parece-me que, quando conseguirmos, vamos aprender muito, não apenas do ponto de vista histórico mas também do ponto de vista filosófico.

${ }^{13}$ The Varieties of Reference, org. por J. McDowell, Clarendon Press, Oxford, 1982. Também em Gareth Evans: Collected Papers, Clarendon Press, Oxford, 1985. 
FP - Diz também no início do livro que não está interessado nas relações causais entre autores e teorias, mas antes na posteridade das ideias que estavam no l'air du temps na viragem do século, ideias que se podem encontrar em autores que não pertencem à tradição analítica, como Brentano e Husserl. ${ }^{14}$ A certa altura, diz, mais precisamente, que a posteridade legítima destas ideias é o que lhe interessa. ${ }^{15}$ Existem intrusos, pessoas que dizem ilegitimamente pertencer à tradição analítica, mas que de facto não pertencem?

MD - Essa é uma excelente pergunta. Os únicos que me ocorrem neste momento como intrusos são pessoas de vários tipos que pensam, de uma maneira ou de outra, que a filosofia acabou. Entre eles, há alguns pretensos seguidores de Wittgenstein. Há, claro, Baker e Hacker, que acham que já não há verdadeiramente mais problemas filosóficos para resolver. ${ }^{16}$ Quando se atingiu o nirvana, como eles, vê-se que as discussões filosóficas não podem deixar de ser destituídas de sentido. Tudo o que se pode fazer é desbobinar a sua história e assinalar as diferentes espécies de teses destituídas de sentido que foram sendo defendidas. Não é mais do que a história dos pseudoproblemas e das soluções sem sentido propostas para os resolver. É tudo. Rorty, nos Estados Unidos, embora de uma perspectiva ligeiramente diferente, defende essencialmente a mesma doutrina.

FP - Na Europa continental, já é defendida há muito tempo.

MD - Ah sim? Por quem?

FP - Por Derrida, por exemplo. Mas também, e mais geralmente, por pessoas que estão convencidas de que há uma descontinuidade fundamental entre os problemas filosóficos tal como são postos em diferentes épocas históricas, ou melhor, entre as sucessivas formulações desses problemas. Neste caso, a doutrina parece ser uma consequência directa de uma concepção historicista da filosofia e não um credo filosófico em que as pessoas

\footnotetext{
${ }^{14}$ Origins of Analytical Philosophy, pp. 2-3.

${ }^{15}$ Op. cit., p. 3: «Falarei das direcções que diversas ideias filosóficas tomaram e de quais foram os seus desenvolvimentos legítimos, sem me preocupar muito com quem leu a obra de quem ou se $\mathrm{X}$ foi buscar uma certa ideia a $\mathrm{Y}$ ou chegou a ela independentemente.»

${ }^{16}$ G. P. Baker e P. M. S. Hacker, Wittgenstein: Understanding and Meaning, vol. 1 de um Analytical Commentary on the Philosophical Investigations, Basil Blackwell, Oxford, 1980; vol. 2: Wittgenstein: Rules, Grammar and Necessity, Basil Blackwell, Oxford, 1985.
} 
se limitam a acreditar cegamente. Em alguns casos, tem levado as pessoas a sentenciar que quaisquer soluções para os problemas filosóficos tradicionais estão a priori condenadas a falhar.

MD - Mas Derrida não se diz da tradição analítica.

FP - Mas a influência continental em Rorty é muito grande. E, através de pessoas como Rorty, em Putnam, por estranho que pareça.

MD - Putnam rejeita muito do que Rorty diz, mas é um tanto ou quanto influenciado por ele. Está bem, classifiquemo-los a todos como intrusos.

FP - Como havemos então de identificar a filosofia analítica? Parece ser uma tarefa bastante difícil. Não podemos fazê-lo dizendo que há um conjunto de posições que todos os filósofos analíticos têm de defender só porque são filósofos analíticos. (A propósito, no continente europeu é assim que algumas pessoas vêem as coisas: os filósofos analíticos são todos empiristas ou positivistas de um tipo qualquer.) Não podemos, por assim dizer, recorrer ao conteúdo, mas também não podemos recorrer ao método. Não existe um só método partilhado por todos os filósofos analíticos quando examinam um problema específico. Então, como havemos de fazer? Em Origins of Analytical Philosophy, o Prof. Dummett adopta um ponto de vista muito forte e restritivo acerca disto, ao defender que só uma análise filosófica da linguagem pode conduzir-nos a uma análise filosófica do pensamento. ${ }^{17}$ Parece-me que, se adoptarmos esse ponto de vista, a obra de Gareth Evans deixa de fazer parte dessa tradição. Talvez ainda faça, mas apenas marginalmente.

MD - Mas, historicamente, é muito claro que faz, não é verdade?

FP - Historicamente faz, e é justamente isso que eu queria mostrar. Podemos também olhar para este problema de um ângulo diferente. Pensemos, por exemplo, na maneira como Nelson Goodman explica aquilo em que consiste o (ou o seu género particular de) nominalismo. Não é tanto que ele esteja empenhado em dizer o que os particulares são. (Concordo que acaba por fazer isso.) Ele está primariamente empenhado em explicar o que

${ }^{17}$ Op. cit., p. 4: «O que distingue a filosofia analítica, nas suas diversas manifestações, das outras escolas é a crença, em primeiro lugar, de que se pode conseguir uma análise filosófica do pensamento através de uma análise filosófica da linguagem e, em segundo lugar, que uma análise abragente apenas [ênfase minha] pode ser conseguida dessa maneira..» 
é descrever o mundo concebido como sendo composto por particulares. ${ }^{18}$ Podia dizer-se: «Bem, essa é uma maneira tipicamente analítica de fazer as coisas». A questão metafísica per se é adiada até que a questão linguística seja cabalmente compreendida ou resolvida, ou talvez até que se tenha encontrado uma formulação satisfatória da questão linguística. Poderíamos encontrar muitos outros exemplos.

Mas deixe-me regressar a Evans e à análise dos pensamentos singulares que ele propõe no artigo «Understanding Demonstratives», a qual, sob muitos aspectos, se funda na rejeição implícita da tese que o Prof. Dummett considera ser a tese fundamental da filosofia analítica. Evans pensa que «atribuir um sentido fregeano a um termo singular é dizer que há um modo particular como o seu referente tem de ser pensado (como referente) de modo a que o termo seja compreendido». ${ }^{19}$ Se adoptarmos a sugestão de Evans, a nossa explicação tem de ir do pensamento para a frase e para o termo. Começamos por explicar o que é ter um pensamento acerca de um objecto particular e depois vamos caracterizar o significado da frase que contém uma ocorrência do termo singular que tem o objecto como seu referente em termos da expressão desse pensamento específico acerca do objecto. Em relação aos nossos pensamentos, as nossas «atitudes epistémicas» para usar uma expressão de Evans - desempenham de facto um papel na determinação do sentido. Assim, qual é o papel, se é que há algum, que devemos atribuir a esta tese da prioridade na identificação da filosofia analítica?

MD - Não podemos certamente recorrer à doutrina, como disse. Pode-se adoptar a atitude segundo a qual, depois de rejeitada a tese da prioridade, estamos na pós-filosofia analítica ou coisa do género. Podia-se fazer dela uma característica definitória. Mas eu acho que isso seria errado, ou pelo menos não ajudava em nada. Penso que a grande diferença entre os filósofos analíticos e os outros é provavelmente a de que todos os filósofos analíticos tomam como ponto de partida algo parecido com o tipo de semântica que subjaz à lógica matemática, i.e., a semântica fregeana. Não necessariamente

\footnotetext{
${ }^{18}$ Ver, e. g., Nelson Goodman, «A World of Individuals», republicado em Problems and Projects, Bobs-Merrill, Indianapolis e Nova Iorque, p. 159.

${ }^{19}$ Gareth Evans, Collected Papers, p. 291-321. A citação é da p. 301. Ver também, no fim da secção IV, p. 308-311, as observações acerca de «estados epistémicos», «ter um objecto em vista» e «apreender» um objecto.
} 
em todos os pormenores, mas no entanto partem de uma estrutura desse género, na qual as partes componentes das frases ou dos pensamentos projecta-se e toma-se a estrutura das frases como modelo para a estrutura dos pensamentos - contribuem para o valor semântico da frase completa ou do pensamento completo. Essa contribuição é algo que vai no sentido de determinar a sua verdade ou assertibilidade.

FP - Portanto, é a composicionalidade que é a característica definitória?

MD - Não apenas a composicionalidade como princípio geral, mas a composicionalidade a par de uma ideia de sintaxe mais ou menos como a da lógica de predicados padrão. Isto é muito vago e é capaz de ser difícil de aplicar a alguns dos filósofos da linguagem comum. Mas penso que, no entanto, é o seu pano de fundo que, de facto, distingue os filósofos analíticos dos outros. Muitos prestam pouquíssima atenção à lógica matemática. Todavia, fez parte da formação de todos eles. Faz parte da perspectiva que têm sobre o significado e o conteúdo.

FP - Nesse caso, é uma questão de estilo? Hoje, muitas pessoas da filosofia analítica não estão interessadas, nem directa nem indirectamente, na lógica matemática.

MD - A lógica matemática é uma vasta estrutura que vai muito para além da parte elementar que até pode ser tudo o que eles aprenderam. Mas a lógica elementar está subjacente à sua concepção de linguagem e de pensamento, ao passo que não o é para aqueles que não têm esse conhecimento elementar. Por acaso não sei como as coisas se passam: ensina-se lógica matemática elementar a quem estudar filosofia numa universidade francesa?

FP - Com certeza, embora a maior parte das pessoas pense que ela é completamente irrelevante para as questões filosóficas profundas. Vêem-na como uma disciplina puramente técnica.

\section{Anti-realismo, verificacionismo e a filosofia da mente}

FP - Tenho uma série de questões para lhe pôr acerca da relação entre a filosofia da linguagem, a filosofia da mente e o anti-realismo. Deixe-me começar com o tipo de anti-realismo que defende, ou melhor, com o tipo de desafio que acha que o realista tem de enfrentar. Muitas pessoas acham que o tipo de semântica que adopta implica o verificacionismo, sob uma forma 
ou outra. Há, por exemplo, a crítica de Michael Devitt ${ }^{20}$, que se apoia certamente numa interpretação deste tipo e também a de Stephen Schiffer que, em Remnants of Meaning, está muito perto de o acusar quer de verificacionismo quer de behaviourismo. ${ }^{21}$ Claro que estas são posições filosóficas que acho que ninguém se atreveria a defender hoje. Em todo o caso, é tentador pensar que uma teoria anti-realista do significado está próxima de (se é que não é mesmo idêntica a) uma teoria verificacionista do significado. Qual é a principal diferença entre o anti-realismo tal como é por si concebido e esta posição um tanto desactualizada? Como distinguiria uma da outra?

MD - Disse que já ninguém é verificacionista. Usei efectivamente no passado o termo «verificação», mas não creio que seja um termo completamente feliz. «Justificação» é melhor e a ideia que eu defendo é que o significado de uma asserção é dado pelo tipo de justificação que poderia sustentá-la.

Há um grande contraste entre o verificacionismo do Círculo de Viena e o tipo de teoria do significado que eu advogo, que parte da sua rejeição — isto é, da minha rejeição - do tipo de atomismo que estava implícito na ideia dos positivistas. Os positivistas falavam como se pudesse considerar-se que cada frase tem um sentido ou um significado independentemente de pertencer a uma linguagem; isto é, independentemente de haver outras frases relacionadas com elas. A verificação consistiria, em última análise, numa certa sequência de experiências sensoriais. Ora, isto não faz, claramente, sentido. Não se pode ter uma teoria do significado que passe ao lado do facto de que as nossas frases fazem parte de uma linguagem e estão relacionadas com outras frases. Em geral, a justificação de qualquer asserção há-de ser qualquer coisa que envolve não apenas uma experiência mas também inferência. Este é justamente o contraste feito no famoso artigo de Quine «Two Dogmas of Empiricism». ${ }^{22}$ Ele acaba por chegar à imagem da linguagem como uma estrutura articulada, com algumas coisas...

$\mathrm{FP}-\ldots$ na periferia ...

${ }^{20}$ Michael Devitt, Realism and Truth, Princeton University Press, Princeton, 1984, cap. 12 .

${ }^{21}$ Stephen Schiffer, Remnants of Meaning, MIT Press, Cambridge, Mass., 1987, secção 8.4.

${ }^{22} \mathrm{O}$ artigo foi reimpresso em Quine, From a Logical Point of View - Nine LogicoPhilosophical Essays, Harvard University Press, Cambridge, Mass., 1953, pp. 20-46. 
MD - ... outras coisas mais no interior, etc. Pense na concepção de significado que ele usa - e eu não estou a dizer que ela me satisfaz tal como está. O facto é que ele não ataca o positivismo só por ser verificacionista. Pelo contrário, a imagem com que ele termina tem tudo a ver com a conformidade entre a estrutura das frases e os valores de verdade atribuídos a essas frases, por um lado, e a experiência, por outro. A experiência tem um impacto na estrutura como um todo. Portanto, é ainda entendida em termos de verificação (ou falsificação, se quiser) e em termos dos ajustamentos que têm de ser feitos na estrutura em função do impacto da experiência. O que ele ataca é a ideia de acordo com a qual cada frase está sozinha, por assim dizer, à espera que algo tenha impacto nela.

FP - Isolada, digamos, do resto da linguagem.

MD -Exactamente. É óbvio que o impacto pode transmitir-se da periferia para o centro e que essa transmissão é feita através de conexões inferenciais, embora ele não especifique exactamente como. Mas o ponto é este: não devemos conceber a justificação de acordo com o modelo empirista segundo o qual ela se resume a uma sequência de experiências sensoriais. Pode tomar qualquer forma que se queira. Por isso é que os positivistas tiveram que traçar aquela dicotomia entre frases empíricas e frases matemáticas.

FP — Ou frases «formais» em geral...

MD - ... que têm um tipo completamente diferente de significado. Mas na concepção que estou a defender há uma escala. Há frases puramente observacionais - se se pode dizer que existem - que apenas se podem verificar directamente pela observação, sem qualquer mediação da inferência. No outro extremo, estão coisas que podemos determinar só pelo raciocínio, como os teoremas da matemática; e a maior parte das coisas ocupa uma posição intermédia. De modo que esse é o contraste entre o verificacionismo e o anti-realismo.

De certo modo, a diferença depende do que se entender por «verificação». Se «verificação» quiser simplesmente dizer que ela é feita em termos da maneira como estabelecemos o valor de verdade de uma asserção, então a minha teoria do significado é verificacionista. Só que não faço questão de que, para cada asserção, haja uma maneira de a estabelecer conclusivamente. Estou perfeitamente preparado para admitir que haja algumas asserções para as quais ela não existe. Há sempre casos em que as asserções se podem deixar cair mais tarde, casos em que podem ser revistas. É uma característica 
do significado de certas frases que elas possam ser confirmadas mas não conclusivamente determinadas quanto ao valor de verdade. Pode chamar-lhe verificacionista nessa acepção geral, se quiser, mas não na acepção atomista do termo, e não com qualquer ideia preconcebida acerca da forma que a justificação pode assumir.

Penso que «justificação» é muito provavelmente um termo melhor do que os outros. Usei originalmente «verificacionista» porque queria chocar um pouco as pessoas. Toda a gente dizia: «O positivismo foi refutado». Nunca apresentaram uma boa explicação do motivo pelo qual tinha sido refutado. Em minha opinião, Quine foi a pessoa que o refutou. A maior parte das pessoas sabia que já não acreditávamos nele mas não tinham nenhum argumento. De modo que ficaram chocadas. O que eu queria dizer era que não era a componente verificacionista do positivismo que estava errada, era a componente atomista.

FP - Ainda quer manter a distinção analítico/sintético?

MD - Quero. Acho que é um erro deitá-la fora.

FP - Portanto, resumindo, acha que o significado de uma asserção é determinado ou fixado, digamos, pelas suas condições de justificação, mas que essas condições não podem ser interpretadas atomisticamente.

$\mathrm{MD}$ - É exactamente isso. E, acima de tudo, penso que essas condições incluirão normalmente uma componente de inferência. Portanto, a linguagem depende da linguagem, por assim dizer.

FP - Mas se as condições de justificação não podem ser formuladas atomisticamente, não deviam então ser formuladas holisticamente? A compreensão de uma frase dependerá sempre da compreensão das frases que estão algures no caminho dela para a periferia ou da periferia para ela. Isto não vai na direcção do holismo?

MD - Não creio. Ficamos com o holismo se abolirmos a distinção entre a periferia e o interior, certo?

FP - Portanto, quer separar a distinção entre a periferia e o interior da distinção analítico/sintético?

MD - Quero ter uma direcção. A inferência, claro, funciona em ambas as direç̧ões. Quero ter uma relação de dependência de significado que vá, falando informalmente, apenas numa direcção, porque penso que não poderíamos ter competência linguística se o holismo estivesse correcto. Penso sem dúvida que não poderíamos proporcionar uma descrição sistemática da 
maneira como a competência linguística funciona se o holismo estivesse correcto.

Posso acrescentar uma coisa? Muitos dos ataques à distinção analítico/sintético têm a ver com uma característica observada nas linguagens naturais, designadamente a de que têm muito de jogo. Isto tem certamente justificação. Se quiséssemos apresentar uma teoria sistemática do significado, teríamos de repartir, por assim dizer, o sentido entre as diferentes palavras e construções duma linguagem e provavelmente não há apenas uma maneira de fazer isso. Se nos pedissem para explicar o que é o significado, ou o tem alguém de saber para saber o significado de uma expressão, provavelmente atribuiríamos o mesmo significado a expressões diferentes. Isto equivale a um certo holismo na nossa compreensão da linguagem. Não temos uma maneira inequívoca de dizer: «Bem, se não percebemos isto, então esta é a palavra cujo significado não sabemos». Por outro lado, contraste isto com o tipo de esquema fregeano rígido em que cada expressão tem o seu sentido perfeitamente determinado. Acho que esse é um ideal pelo qual nos esforçamos conscientemente quando temos necessidade, e temos necessidade quando há disputas ou incertezas acerca do que são as nossas justificações. Construímos teorias, e quando fazemos isso, temos de chegar a acordo acerca daquilo que será considerado o sentido ou a definição deste ou daquele termo, de modo que arrumamos a casa e aproximamo-nos do esquema fregeano.

Portanto, eu não pretendo dizer que a distinção analítico/sintético tem aplicação de maneira absolutamente determinada na nossa linguagem, tal como ela é. Mas não acho que seja algo para deitar fora. Pelo contrário, é algo que precisamos de usar quando estamos a tentar solucionar divergências ou a tentar compreender as justificações daquilo em que acreditamos não mais do que vagamente.

FP - Gostaria de voltar à oposição entre a filosofia da linguagem e a filosofia do pensamento. Falámos dela a propósito da tese da prioridade e do seu papel na identificação da filosofia analítica. Mas eu gostava que falássemos, ainda a propósito da tese da prioridade, sobre a possibilidade de uma filosofia da mente anti-realista.

O Prof. Dummett afirmou que as origens da noção de verdade (ou falsidade) de uma entidade linguística (uma frase, uma asserção) estavam na distinção entre um falante ter objectivamente razão ou não ter objecti- 
vamente razão quando faz a asserção. ${ }^{23}$ Se isso acontecer, a noção de asserção é, de um modo ou de outro, mais fundamental do que a noção de verdade. Ora, é difícil ver como poderíamos produzir uma análise satisfatória da noção de asserção sem ter em conta noções psicológicas: noções como a de crença, desejo, intenção e coisas do género. ${ }^{24}$ De modo que se a noção de asserção é mais fundamental do que a de verdade, e se precisamos da noção de asserção para fornecer uma explicação filosófica da noção de verdade, parece que, para explicar a noção de verdade, temos de apelar para noções psicológicas. Devemos fazer isso?

$\mathrm{MD}$ - Estou a ver. Gostava de dizer algo em primeiro lugar que não é uma resposta directa à questão, mas serve para clarificar a posição que vou defender. Penso que a noção de asserção correcta e incorrecta é muito mais primitiva do que a noção de verdade. Em filosofia há imensos exemplos de pessoas que dizem: «Estes tipos de elocução específicos não correspondem a asserções com condições de verdade determinadas». Diz-se isto acerca das condicionais, por exemplo. Hilbert disse-o acerca das asserções matemáticas com quantificadores ilimitados. Ora o que eles estão a dizer é que tem de se interpretar essas elocuções como algo que exprime uma pretensão. É muito claro nos exemplos mais simples - por exemplo, na interpretação que Hilbert faz das asserções quantificadas existencialmente como comunicações incompletas. A ideia é que temos justificação para as fazer se pudermos apresentar um exemplo. Nesta perspectiva, a distinção crucial não é entre verdade objectiva e falsidade objectiva. A distinção crucial é formulada em termos do que nós podemos fazer, em termos de se nós podemos ou não justificar a nossa pretensão. E isto ajusta-se perfeitamente à ideia de uma asserção correcta versus uma asserção incorrecta.

A diferença entre esta perspectiva e considerar que uma asserção tem um valor de verdade objectivo é que as condições de verdade têm de ser independentes da minha situação epistemológica, de tudo o que eu seja capaz de fazer - a menos, claro, que a asserção seja sobre mim. A ideia é então a de que a asserção é determinadamente verdadeira ou falsa independentemente de eu a poder justificar ou não. Ao passo que na outra perspectiva consideramo-la apenas em termos de eu poder justificar a pretensão que exprimo. É isso que eu tenho em mente quando digo que a noção de asserção abre

${ }^{23}$ Truth and Other Enigmas, p. xvii.

${ }^{24}$ Ver, e. g., de novo Truth and Other Enigmas, p. xvii. 
caminho, por assim dizer, à noção de verdade. Mas tem de se ir muito mais longe para ficar com a noção de verdade propriamente dita. Digamos que é só o início do caminho nessa direcção. Para chegar à noção de verdade, temos de perguntar: «Por que razão não posso considerar isto como algo que exprime, pura e simplesmente, uma pretensão (se é que não posso)? Por que tenho de lhe dar uma apreciação objectiva, independente de mim?»

Penso que o passo no seu argumento que devo rejeitar é a tese de que a asserção tem de ser explicada psicologicamente. Sei que houve uma fase em que quer Russell quer Wittgenstein defenderiam essa tese, mas eu não acredito nela. Acho que é uma questão complicada. Temos a asserção como um acto exterior. Há uma frase que tem de ser compreendida como tendo sido proferida assertivamente, e há também o acto interior do juízo, quando se ajuíza que algo é verdadeiro. Penso que é preferível considerar o juízo como a interiorização do acto exterior da asserção do que ao contrário, i.e., do que considerar a asserção como a expressão de um estado ou acto interno.

Há uma pergunta algures nas Investigações Filosóficas: «Qual é o jogo de linguagem da asserção?» Na verdade, Wittgenstein acha que a asserção não é uma coisa única. Há vários casos diferentes. Mas acho que é, no entanto, uma pergunta perfeitamente correcta.

Temos muito pouco a tentação de explicar o que é dar uma ordem em termos psicológicos. Normalmente, quando uma pessoa que dá uma ordem está numa posição de autoridade em relação a outra, presume-se normalmente que ela quer que a outra pessoa faça o que ela lhe ordena que faça. Mas não se tem de presumir que ela tem outros motivos para dar a ordem. $\mathrm{O}$ facto é que, se ela está realmente numa posição de autoridade, ela está apenas a dar a ordem e isso tem certos efeitos, seja qual for a razão pela qual ela deu essa ordem. Aquilo que temos de fazer é descrever o jogo de linguagem das ordens e penso que o mesmo é válido para a asserção. Nesse caso não é tão óbvio, porque as consequências não são tão claras como as consequências de dar uma ordem. Isso torna a coisa muito mais complicada de descrever, mas eu penso que é aquilo que tem de ser descrito com o jogo de linguagem da comunicação, que implica dizer coisas às pessoas, e não qualquer coisa que diga respeito a estados internos. De maneira que não acho que tenhamos de apelar para a intenção ou para a crença; ou então, se tivermos de apelar para a intenção, é só numa fase muito posterior, digamos. 
FP - Portanto, aquilo de que precisamos não é mais do que a descrição do acto linguístico da asserção? E é possível dá-la sem ter em conta intenções, crenças, desejos e outras atitudes proposicionais?

MD - É disso que tenho esperança. Quer dizer, se me disser «Está bem. Então faça lá!» — eu não consigo. Porque depende de toda a teoria do significado e não sei exactamente como fazer.

FP - Então não lhe peço. Peço-lhe antes outra coisa. A minha segunda questão acerca da oposição entre filosofia da linguagem e filosofia da mente diz directamente respeito ao conteúdo do debate entre realismo e anti-realismo. Este debate, tal como o concebe, não pode ser apenas acerca de entidades linguísticas (asserções, frases) por (parece-me) três razões, pelo menos. Para começar, devia também ser acerca de crenças e estados de crença porque nós também avaliamos crenças e estados de crença em termos de verdade e falsidade. Em segundo lugar, o significado é uma noção cognitiva. É tudo aquilo que os falantes e os agentes competentes compreendem ou sabem quando compreendem o significado das frases ou quando sabem qual ele é, e a questão de saber como é que o significado é representado mentalmente é altamente relevante para o debate. Por fim, a questão de saber se a noção de verdade tem de ser restringida epistemologicamente diz directamente respeito à natureza do conceito de verdade que possamos ou não construir legitimamente.

Dado que o debate não pode ser apenas acerca da compreensão linguística e tem de ser também acerca da formação de conceitos, não seria possível (para não dizer obrigatório) formulá-lo como um debate de filosofia da mente, enquanto tal? Um debate não apenas acerca do significado das frases mas também acerca de conteúdos mentais?

$\mathrm{MD}$ - Bem, pode ser que concorde consigo. Eu não pensaria certamente que era um tópico com grande relevância para estas disputas metafísicas sobre o realismo - como de facto penso - se pensasse que era apenas uma questão de linguagem, um bocado de semântica. Falávamos há bocado na tese da prioridade. Ora, mesmo que sejamos adeptos de Evans ou de Peacocke e que pensemos que temos de descrever a estrutura dos nossos pensamentos independentemente da sua expressão linguística, surge ainda assim a mesma dicotomia entre uma explicação em termos de condições de verdade $-\mathrm{o}$ que tem de ser o caso para o pensamento ser verdadeiro - e uma explicação em termos de, digamos, justificação, com base na nossa capacidade ou incapacidade de o reconhecer como verdadeiro. De modo que se 
põe aqui a mesma questão, tal como se põe, explicitamente, em Evans e em Peacocke.

FP - Devemos concluir que não há vantagem em considerá-lo como um debate de filosofia da mente?

MD - Não penso que houvesse qualquer vantagem. Como sabe, eu acredito na tese da prioridade. A diferença entre essas duas vias é que a via da filosofia da mente, ou da filosofia do pensamento, tem tendência para ser solipsista. Fala-se de sujeitos individuais, do conteúdo que um sujeito individual pode atribuir a um pensamento, como ele reconhece esse pensamento como verdadeiro, e assim por diante. E não tem muito a ver (pelo menos habitualmente) com a comunicação, ao passo que eu acho que provavelmente não se obtém uma boa resposta se não se discutir o assunto em termos de comunicação. Mas esta é uma questão muito lata.

FP - Há duas questões distintas no que diz respeito à tese da prioridade. Há a questão metodológica e há a questão acerca do conteúdo do debate realismo versus anti-realismo. Um problema é o de saber se a filosofia do pensamento pode ser abordada apenas através da filosofia da linguagem, ou seja, se a linguagem é anterior ao pensamento na ordem da explicação. Esta é uma questão metodológica. Uma questão diferente é decidir se o debate é também acerca de conteúdos mentais. É-o claramente no sentido em que, se o que está a ser debatido é saber se o significado de uma frase é determinado pelas suas condições de verdade, então o problema de saber se o conteúdo do pensamento expresso pela frase é determinado pelas suas condições de verdade faz também parte do debate.

Portanto, há na verdade duas questões diferentes: a metodológica e a de conteúdo. Parece-me que a sua forte posição metodológica quanto à primeira é irrelevante para a segunda. São logicamente independentes. De modo que a revogação do axioma fundamental da filosofia analítica não faz diferença e é perfeitamente legítimo começar com a questão do conteúdo dos nossos pensamentos. Por outro lado, vamos dar aos mesmos problemas.

MD - Acho que tem toda a razão. Acho que é uma questão de metodologia. Ficamos, de facto, com os mesmos problemas. E é por isso que em grande medida, como disse, a tal revogação não impede grandemente a comunicação entre as pessoas de um lado e do outro. Mas há um ponto em que elas divergem e que tem a ver com metodologia. Isto é: o filósofo do pensamento não presta muita atenção a nada que tenha a ver com interacção verbal, ao passo que, obviamente, a linguagem é prévia na ordem da expli- 
cação. A linguagem é algo de comunitário. É, em primeiro lugar, um meio de comunicação.

FP - E é justamente porque é algo de comunitário que defende a tese da prioridade?

$\mathrm{MD}-\mathrm{Sim}$.

FP - Mas os pensamentos fregeanos também são uma coisa comunitária. Pode muito bem argumentar-se a favor da tese da prioridade com base no facto de ela ter a vantagem de evitar o psicologismo. Mas qual é o erro do psicologismo, senão o de defender que os pensamentos fazem parte do fluxo da consciência? Parece-me que uma questão crucial é então decidir se a confusão entre Gedanke e Vorstellung se segue, necessariamente, da rejeição da tese da prioridade. Suponha que adoptamos a sugestão de Evans que discutíamos há pouco. Estamos, só por isso, a fazer psicologia, no sentido criticado por Frege e Husserl? Temos de argumentar que o modo como o referente é pensado, o seu modo de apresentação ao nível do pensamento, é parte do fluxo da consciência? Nem que fosse só por motivos fregeanos, podia dizer-se: «Sim, há razões para defender a tese da prioridade. Ela oferece uma protecção eficaz contra os erros do psicologismo». Mas é essa confusão entre Gedanke e Vorstellung realmente inevitável? Não há maneiras de evitar essa confusão ao mesmo tempo que se rejeita a tese da prioridade?

MD - Claro que é muito apressado dizer apenas: «Mal se faça isso, cai-se no psicologismo». Não é isso que eu digo. Mas acho que é necessário que o filósofo do pensamento, tanto como o filósofo da linguagem, respeite o princípio do contexto. Se tivermos em consideração o que Evans diz acerca dos modos específicos de pensar sobre um referente e o que ele diz sobre os referentes singulares, os pensamentos singulares e assim por diante, temos de reconhecer que a maneira como pensamos sobre um objecto particular é algo que faz parte de um pensamento completo. O modo de conceber um objecto é um ingrediente de um pensamento completo. Não faz sentido falar dele independentemente do...

FP - ... contexto em que está inserido.

MD - Exactamente: independentemente do contexto que consiste em pensar que algo é verdade sobre o objecto em questão. Tem de se perguntar: «O que é ter um pensamento completo?» A menos que se caia em explicações psicologistas, tem de se considerar um pensamento como o objecto de uma atitude proposicional, como Frege fez. É acreditar em algo ou acreditar 
que algo é verdade. Tem de ser o conteúdo de uma atitude proposicional. É exactamente o que Peacocke faz. Constrói tudo a partir de uma caracterização das atitudes que um ser que talvez não tenha uma linguagem pode manifestar. ${ }^{25}$

FP - E para ele os pensamentos são pensamentos fregeanos, Gedanken.

MD - São exactamente isso, e são os objectos de crenças ou desejos, ou uma destas coisas. Ainda não acredito que um projecto destes funcione, mas não penso que o possamos acusar de psicologismo, sem mais nem menos. Se se pudesse dar uma caracterização destas atitudes proposicionais sem fazer referência à sua expressão, a coisa funcionava. Não creio que Peacocke ou quem quer que seja tenha realmente mostrado que é possível.

FP - É muito pessimista no que diz respeito ao que se pode esperar da filosofia da mente. E quanto à ciência cognitiva?

$\mathrm{MD}$ - Sou é pessimista quanto à ciência cognitiva. Não sou pessimista em relação às pessoas - como John Campbell - que se voltam para a filosofia do pensamento. Para começar, tenho a certeza de que vão descobrir muitas coisas nas suas investigações, mesmo que toda a sua premissa básica esteja errada, mesmo que não tenham razão ao abolir a tese da prioridade. Em segundo lugar, acho que é muito interessante ver até onde é que se pode levar a coisa. Uma razão pela qual isto é interessante é que, se a coisa for completamente bem sucedida, então a tese da prioridade está errada e não terá qualquer interesse. Mas mesmo que não esteja errada, será muito interessante ver até onde, especificamente, um programa de trabalho construído sobre a rejeição dessa tese poderá ir.

FP - E quão longe pode ir.

MD - Quão longe pode ir exactamente. É uma questão muito obscura. Até Frege pensava que a tese da prioridade era apenas relativa a nós. Ele pensava que seres sem linguagem podiam apreender os mesmos pensamentos que nós, apenas sem a roupagem da expressão linguística. Mas ele não deu nenhuma explicação de como isso seria. Tudo o que disse acerca disto é que não era contraditório. O que é que isto quer dizer? Se as pessoas que se voltam para a filosofia da mente tiverem razão, hão-de dar uma explicação para isto. É apenas um facto contingente - se é que é um facto - que nós somos capazes de apreender pensamentos por meio da linguagem. O que é

${ }^{25}$ Ver, e.g., Cristopher Peacocke, Thoughts: An Essay on Content, Basil Blackwell, Oxford, 1986. 
que nós temos que torna isso possível? Todas estas questões são genuínas e muito interessantes. Espero que nos revelem alguma coisa.

FP - Há uma tendência muito forte na filosofia analítica para optar pela filosofia da mente em detrimento, por assim dizer, da filosofia da linguagem. É muito óbvio que as pessoas, nos Estados Unidos, estão a ir nesta direcção. Cada vez há mais filosofia da mente.

MD - Muita dela é de muito má qualidade, em minha opinião.

FP - A distância entre a filosofia inglesa e americana parece estar a alargar-se cada vez mais nesse ponto. Isso deve-se, em grande parte, ao enorme impacto da ciência cognitiva nos Estados Unidos.

$\mathrm{MD}$ - Penso que é verdade. E isso não me preocupa, porque eu de facto penso que a filosofia americana está, em grande parte, no mau caminho.

FP - Está a referir-se, em particular, à filosofia da mente?

MD - Claro que isto não se aplica a Kripke nem a Putnam e a Davidson também não. Mas a tendência geral é para ir na direcção do cientismo, o que me parece uma opção estéril.

FP - Está a falar do materialismo, do fisicalismo, etc?

MD - Tudo isso. Não vai levar a lado nenhum.

FP - Levou pelo menos a uma coisa. A posição em que estamos agora é exactamente o oposto da posição em que Brentano e Husserl estavam. Eles consideravam a intencionalidade como a marca irredutível do mental, ao passo que nós achamos que somos apenas carne e osso, seres físicos, e perguntamos: «Como pode uma entidade destas ter intencionalidade? Como podem as máquinas (ou o que quer que seja que possa ser descrito em termos puramente físicos) ter intenções e pensamentos?» E tentamos explicar a intencionalidade em termos naturalistas.

MD - Está bem, essa é uma pergunta filosófica a fazer. Mas eu espero realmente que a filosofia inglesa olhe muito mais para o que está a acontecer nos outros países europeus e muito menos para aquilo que está a acontecer na América. É a língua que leva as pessoas a fazer isto. É muito mais fácil ler artigos em revistas americanas. É espantoso. Há estas pessoas todas como Jonathan Barnes, Kevin Mulligan, Peter Simmons e assim - que conseguem adaptar-se ao ensino no estrangeiro. Muito poucas pessoas com um grau académico fazem isso. Sobretudo, penso eu, por causa da língua. Isso vem do ensino de línguas nas escolas. Talvez devêssemos ter cursos de línguas para estudantes graduados; exigir que eles dominassem pelo menos uma língua europeia. 
FP - Voltando à situação nos Estados Unidos. É muito notório que o seu trabalho, por exemplo, não tem muita audiência lá. Muito poucas pessoas se dão sequer o trabalho de o ler. Putnam é um dos que o lê. Brian Loar e Paul Horwich, que ensina na América, também o leram cuidadosamente. Com Gareth Evans passava-se a mesma coisa. Poucos filósofos americanos se deram ao trabalho de o ler.

MD - É verdade, e foi pena. Putnam foi parcialmente responsável por isso. Fez uma recensão terrível do livro The Varieties of Reference e arrasou-o completamente. Não sei por que razão fez isso. É um erro de apreciação muito grave. Talvez não tenha tido muita influência. Pode ter sido só um sintoma e não uma causa. Não sei. Mas é verdade que deviam ler Evans, é um erro muito grave não o fazer. Há muitas coisas de valor nesse livro.

\section{O anti-realismo e a ética}

FP - Tenho uma última pergunta. É sobre ética. Talvez não exista uma doutrina, um ponto de vista global ou uma Weltanschauung filosófica consistente a que se possa chamar o anti-realismo global e que consista no anti-realismo acerca da matemática $e$ do mundo natural $e$ da vida mental das outras pessoas $e$ dos agentes morais, etc.

MD - Pode ser que haja.

FP - Mas o facto é que nunca argumentou a favor desse tipo de posição. Há, no entanto, um conjunto de disputas filosóficas que partilham o formato comum de, como diz, um conflito entre uma visão ou interpretação realista e uma visão ou interpretação anti-realista das asserções de uma dada classe, i.e., asserções matemáticas, asserções acerca do mundo natural, da vida mental das outras pessoas, das normas éticas, etc. Este debate - tal como o concebe, e tal como algumas pessoas (como Crispin Wright) o conceberam depois de si, aplica-se certamente também à ética. Há, digamos, a questão do realismo acerca dos factos morais e dos valores morais. A minha pergunta é: em que deve consistir o desafio anti-realista ao realismo ético?

Deixe-me formular isto de uma maneira mais precisa. Há pelo menos duas maneiras de formular o realismo moral: em termos de factos e em termos de valores. Em termos de factos, consistiria no seguinte: há factos morais objectivos que são constitutivos do mundo e o objectivo da deliberação moral é descobri-los. Existe, digamos, o facto objectivo de que a escravatura é injusta. Mas também podíamos exprimir o realismo moral em ter- 
mos de valores. O realismo moral consistiria então no seguinte: algumas acções, práticas e instituições têm de ser adoptadas ou, pelo contrário, criticadas e abandonadas, consoante fomentem ou promovam valores que nós estamos objectivamente justificados em aceitar ou, pelo contrário, em rejeitar. O objectivo da deliberação moral neste caso é descobrir que valores devemos adoptar e que valores devemos rejeitar, e quando descobrirmos isso, descobrimos algo de objectivo. Para voltar ao exemplo da escravatura, um realista poderia exprimir a sua posição argumentando que os valores associados à instituição e à prática da escravatura têm de ser abolidos e que as razões que temos para o fazer são razões objectivas. O objectivo da deliberação moral é ser capaz de tomar decisões em todos os casos que possam ser menos óbvios do a escravatura - por exemplo, a eutanásia ou o aborto.

Parece-me que o argumento anti-realista contra o realismo moral interpretado em termos de factos deve ser um argumento que defenda uma forma ou outra de não cognitivismo. Se estou a ver bem, um anti-realista deve argumentar que as asserções morais são cognitivamente vazias no sentido em que não podemos descrever factos morais. Não existem, pura e simplesmente, factos morais e, portanto, não podem ser descobertos. A pergunta que lhe quero fazer é a seguinte: como deveria ser um argumento anti-realista contra o realismo moral interpretado em termos de valores? Será que um anti-realista tem de defender uma forma ou outra de relativismo e argumentar que as nossas acções, costumes, instituições, etc., ou são justos ou são injustos relativamente a um conjunto de crenças de raiz cultural que formam, por assim dizer, as condições contextuais das nossas justificações, de tal modo que as nossas «justificações» éticas não podem deixar de ser, de um modo muito forte e não eliminável, derivadas do preconceito?

Está disposto a argumentar a favor de alguma forma de anti-realismo em ética? Se sim, qual é a sua posição? E como pensa argumentar a favor dela?

MD - Vou tentar dar-lhe uma resposta. Só posso dar-lhe uma resposta muito programática porque, para vergonha minha, nunca dediquei muito tempo a pensar nisso. Não por pensar que é perfeitamente dispensável. Acontece apenas que não pensei muito na questão.

Parece-me, pelo menos, que a aplicação destas ideias anti-realistas à ética tem de provocar uma mudança na formulação dos termos do debate, pela seguinte razão. O tipo de anti-realismo que tenho em vista não é nenhuma espécie de subjectivismo. É completamente objectivo ou presume a objectividade, no sentido em que saber se uma asserção é ou não justificada é uma questão objectiva. Pense só no caso da matemática. Saber se se tem ou não 
uma demonstração de uma asserção é uma questão objectiva. Não se trata de saber se a asserção é verdadeira no que diz respeito a uma realidade moral objectiva. Trata-se da expressão de uma pretensão cuja justificação é objectivamente correcta ou não. Se se adoptar em ética qualquer coisa como uma posição anti-realista, neste sentido, ela não seria, claramente, uma posição subjectivista. E acho que classificá-la como não cognitivista seria também bastante incorrecto. A justificação é uma questão de justificação cognitiva. Por outro lado, não se deve pensar que a única alternativa a uma explicação subjectivista da ética seria um tipo de esquema realista que encarasse as asserções éticas como algo que descreveria uma realidade que existe independentemente de nós, ou fazendo asserções objectivamente verdadeiras ou falsas. A explicação destas asserções tem de dar conta do facto de que a pessoa que as faz é, em princípio, capaz de as justificar. Teria de se investigar isto e eu não sou capaz de dizer muito acerca do tipo de justificação de que nós precisaríamos exactamente, que características seriam constitutivas da justificação de uma asserção ética.

FP — Em particular, de uma asserção normativa.

MD - Exacto. Não vou tentar agora. Mas esse seria o tipo de opção que se teria de tomar se se quisesse ver em que consistia o anti-realismo em ética. Ou seja, provavelmente seria uma posição intermédia.

FP - Talvez qualquer coisa do tipo da posição de Wiggins. Wiggins defende o cognitivismo associado a um subdeterminismo no que diz respeito às afirmações morais. ${ }^{26}$ À primeira vista, o cognitivismo é um aliado natural do realismo. Mas se Wiggins tem razão, isto não é mais do que uma intuição superficial. Também temos tendência para pensar que o teísmo é um aliado natural do realismo. Fala do teísmo no fim de The Logical Basis of Metaphysics. $^{27}$

MD - Não muito. ismo.

FP - Talvez. Mas sugere que o teísmo não é um aliado natural do real-

MD - É a favor disso que gostaria de argumentar. Essa pode ser uma transição ilegítima, mas deixe-me ir a Platão e ao velho dilema: «uma coisa é um bem porque Deus a quer ou Deus quere-la porque é um bem?» A. J. Ayer gostava muito de argumentar que a segunda parte da questão contém uma sugestão inválida e que, portanto, Deus é irrelevante para o juízo ético.

${ }^{26}$ Ver Needs, Values, Truth, Basil Blackwell, Oxford, 1987, especialmente p. 124$-132$.

${ }^{27}$ O texto revisto das conferências William James de Harvard (1976) está agora publicado sob o título The Logical Basis of Metaphysics, Duckworth, Londres, 1991. As observações sobre o teísmo encontram-se no capítulo 15, pp. 348-51. 
Wittgenstein, pelo contrário, toma muito fortemente posição a favor da primeira e considera a segunda completamente superficial. Ora, parece-me que, evidentemente, se alguém tem razões para pensar que Deus quer, ou nos ordena ou deseja, que nós ajamos de certa maneira, isso, só por si, tem de ser uma razão suficiente para agir dessa maneira. Mas então tem de se poder recorrer a alguma maneira específica de saber qual é a vontade de Deus. Ao passo que o ponto de vista tradicional tem sido o de que somos capazes de discernir o bem e o mal e deduzir daí o que Deus quer que façamos. Deixe-me só dizer que o nosso argumento tem de certeza de ir nesta segunda direcção.

FP - Bem, acho que falámos bastante tempo. Talvez pudéssemos parar aqui. Muito obrigado.

MD - Obrigado. Gostei muito da nossa discussão.

Fabrice Pataut

(Tradução de Pedro Santos)

Institut d'Histoire et de

Philosophie des Sciences et des Tecnhiques

Université de Paris 1, França 